\title{
Synthesis and properties of a novel brominated oligomycin A derivative
}

\author{
Lyudmila N Lysenkova ${ }^{1}$, Konstantin F Turchin ${ }^{1}$, Alexander M Korolev ${ }^{1}$, Valery N Danilenko ${ }^{2}$, Olga B Bekker ${ }^{2}$, \\ Alexey S Trenin ${ }^{1}$, Alexander A Shtil ${ }^{3}$ and Maria N Preobrazhenskaya ${ }^{1}$
}

The Journal of Antibiotics (2012) 65, 223-225; doi:10.1038/ja.2012.4; published online 8 February 2012

Keywords: ATP; bromo-oligomycin A; bromotetrahydropyrane; cytotoxicity; macrolide antibiotic; oligomycin A

Oligomycins belong to the class of highly functionalized macrolide antibiotics that contain the hydroxyl groups, the lactone and spiro moieties, as well as the double bonds. The mechanism of cytocidal activity of oligomycins involves the inhibition of oxidative phosphorylation by preventing ATP synthesis. Design of new compounds on oligomycin A scaffold is of interest as ATP synthase inhibitors are drug candidates for the treatment of bacterial infections and cancer. ${ }^{1}$ Recently, we reported the examples of modification at the $\mathrm{C}_{7}$ carbonyl group and the $\mathrm{C}_{2}=\mathrm{C}_{3}$ double bond of the antibiotic. ${ }^{2}$ In search of selective methods to modify oligomycin A (1), we carried out bromination of (1) with NBS in DMF at neutral $\mathrm{pH}$; this procedure yielded a mono-bromo derivative (2) in $45 \%$ yield (Figure 1 ). NMR studies showed the presence of a single bond $\mathrm{C}_{16}-\mathrm{C}_{17}$ (instead of the double bond in (1) and a tetrahydropyrane cycle due to the formation of $\mathrm{C}_{13} \mathrm{H}-\mathrm{O}-\mathrm{C}_{17} \mathrm{H}$ bond confirmed by a low field shift of $\mathrm{C}_{13}$
( $\Delta \sim 10$ p.p.m.) in comparison with ${ }^{13} \mathrm{C}$ NMR spectrum of (1) (81.73 and 72.15 p.p.m. for $\mathrm{C}_{13}$ in (1) and (2), respectively) (Table 1). ${ }^{2}$ The tetrahydropyrane ring contains $\mathrm{Br}$ in position $\mathrm{C}_{16}$. The spin coupling constants in the tetrahydropyrane ring correlate with 'chair' conformation and correspond to the following orientation of hydrogen atoms: $\mathrm{C}_{13} \mathrm{H}_{\mathrm{eq}}, \mathrm{C}_{14} \mathrm{H}_{\mathrm{eq}}, \mathrm{C}_{16} \mathrm{H}_{\mathrm{ax}}$ and $\mathrm{C}_{17} \mathrm{H}_{\mathrm{ax}}$. On the basis of these coupling constant values and taking in mind that oligomycin A moiety has $13 S$ and $14 R$ configuration, ${ }^{3}$ we can ascribe $13 S, 14 R$, $16 R$ and $17 S$ stereochemistry to bromooligomycin (2). This structure represents a new skeleton in this type of antibiotics.

The NMR spectra were elucidated using homo ${ }^{1} \mathrm{H},{ }^{1} \mathrm{H}(2 \mathrm{D}$ COSY) and hetero ${ }^{1} \mathrm{H},{ }^{13} \mathrm{C}(2 \mathrm{D}$ HETCOR $)$ correlation as well as ${ }^{1} \mathrm{H}$ and ${ }^{13} \mathrm{C}$ 1D spectra of $(\mathbf{1})$ and its derivatives and were registered using unity +400 (Varian, Palo Alto, CA, USA) spectrometer at $400.0 \mathrm{MHz}$ for ${ }^{1} \mathrm{H}$ nuclei, and at $100.6 \mathrm{MHz}$ for ${ }^{13} \mathrm{C}$ nuclei.

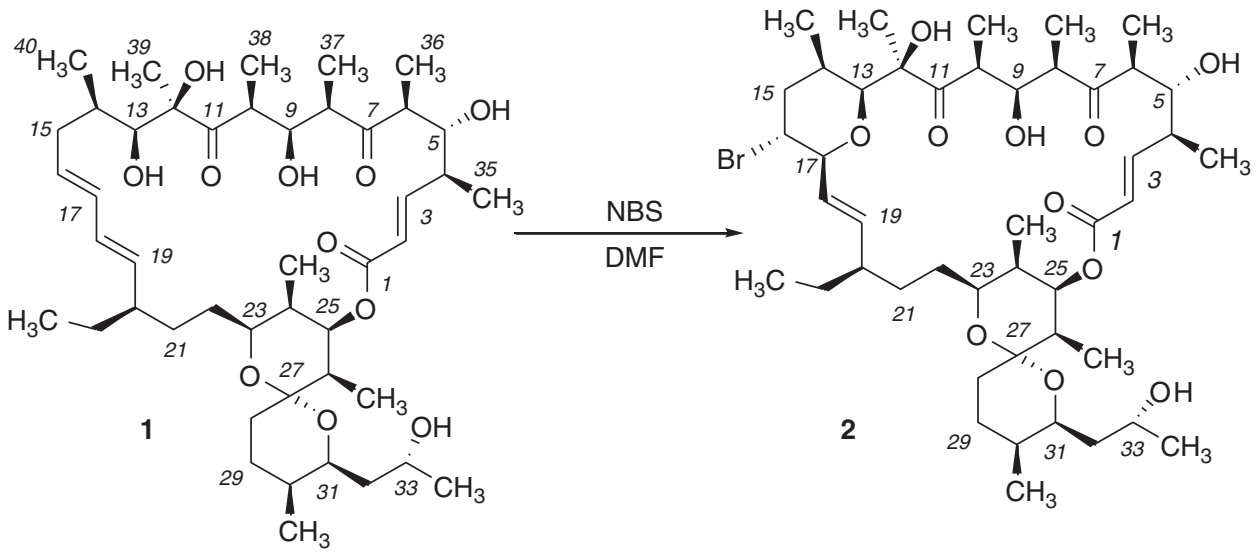

Figure 1 Synthesis of the bromo derivative of 1 (compound 2).

${ }^{1}$ Gause Institute of New Antibiotics, Russian Academy of Medical Sciences, Moscow, Russian Federation; ${ }^{2}$ Vavilov Institute of General Genetics, Russian Academy of Sciences, Moscow, Russian Federation and ${ }^{3}$ Blokhin Cancer Center, Russian Academy of Medical Sciences, Moscow, Russian Federation

Correspondence: Professor MN Preobrazhenskaya, Gause Institute of New Antibiotics, Russian Academy of Medical Sciences, 11 B. Pirogovskaya Street, Moscow 119021, Russian Federation.

E-mail: mnp@space.ru or mpreo@hotmail.com

Received 13 October 2011; revised 22 December 2012; accepted 11 January 2012; published online 8 February 2012 
Table 1 The ${ }^{1} \mathrm{H}$ and ${ }^{13} \mathrm{C}$ NMR spectra of 1 and 2

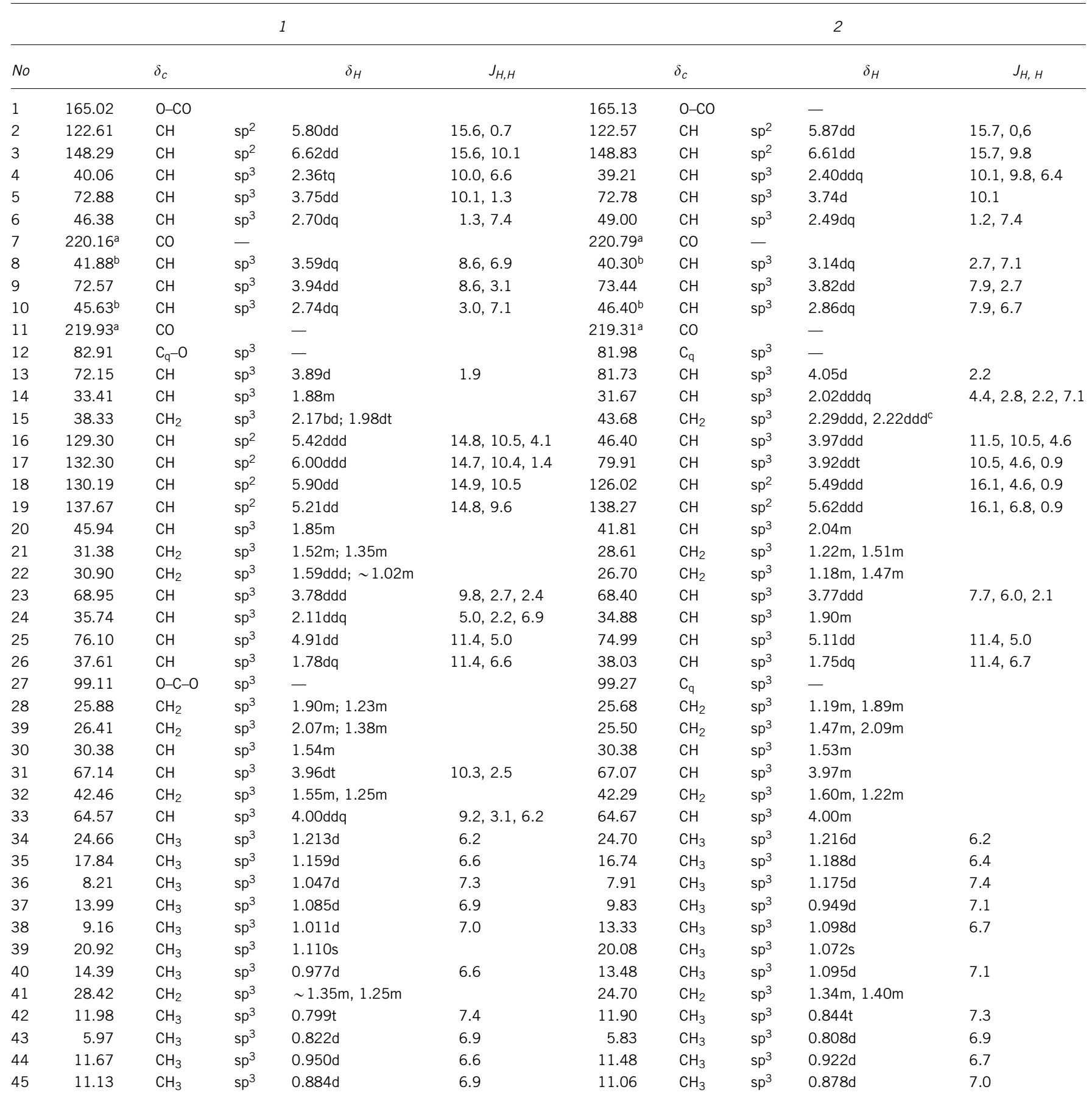

aReverse assignments of signals are possible.

b5-OH: $\delta 3.07,{ }^{3} \mathrm{~J}=2.6 \mathrm{~Hz} ; 13-\mathrm{OH}: \delta 2.12,{ }^{3} \mathrm{~J}=8.3 \mathrm{~Hz}$.

${ }^{\mathrm{c}} 15-\mathrm{CH}_{2}: \mathrm{H}_{\mathrm{eq}}: \delta 2.29 \mathrm{ddd}, \mathrm{J} 13.2,4.6,2.8 \mathrm{~Hz} ; \mathrm{H}_{\mathrm{ax}}: \delta 2.22 \mathrm{ddd}, \mathrm{J} 13.2,11.5,4.4 \mathrm{~Hz}$.

The structure of (2) is membranous; a membranous structure has been demonstrated also for the product of the interaction of (1) with hydroxylamine. ${ }^{2}$ It is likely that the formation of such structures is typical for this 26-membered macrolide as well as for 14-membered antibacterial macrolides (for example, erythromycin and its derivatives). ${ }^{4}$

Bromo-oligomycin A (2) was low cytotoxic against HCT116 human colon cancer cell line and $\mathrm{K} 562$ human leukemia cell line ( $\mathrm{IC}_{50}$
$16.0 \pm 2.2$ and $9.0 \pm 1.4 \mu \mathrm{M}$, respectively), whereas the parental compound (1) was significantly more potent $\left(\mathrm{IC}_{50} 3.3 \pm 1.0\right.$ and $3.0 \pm 1.0 \mu \mathrm{M}$, respectively) as determined by MTT-test after a $72 \mathrm{~h}$ incubation. ${ }^{5}$ Furthermore, (2) was weakly active against Streptomyces fradiae strain that is extremely sensitive to (1) $(250 \mathrm{~nm}$ per disk and $0.001 \mathrm{~nm}$ per disk, respectively).

A lowered potency of (2) for actinobacterial cells correlated with a decreased activity against filamentous fungi (moulds) and yeast. 
Compound (1) was highly active against Aspergillus niger ATCC 16404 and Fusarium oxysporum VKM F-140 strains (MICs 0.125 and $1 \mu \mathrm{g} \mathrm{ml}^{-1}$, respectively) and moderately active against Candida albicans ATCC 14053 and Cryptococcus humicolus ATCC 9949 (MICs 4 and $2 \mu \mathrm{g} \mathrm{ml}^{-1}$, respectively, after a 24-h exposure). Compound (2) revealed the activity only against $C$. humicolus ( $\mathrm{MIC} 2 \mu \mathrm{g} \mathrm{ml}^{-1}$ ), whereas for other studied fungi and yeast strains (2) was practically inert (MIC $>16 \mu \mathrm{g} \mathrm{ml}^{-1}$ ). Determination of MICs was carried out according to NCCLS, Standards M27-A and M38-A. ${ }^{6,7}$

Low biological activities of compound (2) may be explained by distorted conformation of oligomycin A derivative in comparison with the starting antibiotic due to the formation of the webbed structure and also by the absence of free 13-OH group that participates at the interaction with oligomycin A target in cells. It was supposed that in oligomycins the hydroxyl groups could function as donors or acceptors of hydrogen bonds. ${ }^{8}$

\section{EXPERIMENTAL PROCEDURE}

Oligomycin A ((1); purity $95 \%)$ was obtained in the Research Center for Biotechnology of Antibiotics BIOAN, Moscow using the Streptomyces avermitilis NIC B62 strain (production of $(\mathbf{1}) \sim 1 \mathrm{gl}^{-1}$ ). Fermentation was performed for 8 days at $28^{\circ} \mathrm{C}$ in liquid medium. Isolation and purification involved the extraction with acetone-hexane mixture followed by crystallization.

\section{Synthesis of bromo-oligomycin A (2).}

To a solution of $(\mathbf{1})(1.0 \mathrm{~g}, 1.3 \mathrm{mmol})$ in dry DMF $(10 \mathrm{ml}) \mathrm{N}$-Br-succinimide (1-bromopyrrolidine-2,5-dione) $(0.25 \mathrm{~g}, 1.41 \mathrm{mmol})$ was added, the reaction mixture was stirred at room temperature for $2 \mathrm{~h}$ and analyzed by TLC in $\mathrm{CHCl}_{3}-\mathrm{MeOH}(10: 0.5)$. The mixture was diluted with water; the reaction product was extracted with toluene, washed and dried over $\mathrm{Na}_{2} \mathrm{SO}_{4}$. Then the reaction product was purified by column chromatography on silica gel 60 (Merck) in $\mathrm{CHCl}_{3}-\mathrm{MeOH}(50: 0.5)$ to give $0.45 \mathrm{~g}(45 \%)$ of (2) as colorless amorphous powder. MW calcd. for $\mathrm{C}_{45} \mathrm{H}_{73} \mathrm{BrO}_{11}$ 868.4336. Found in ESI-mass spectrum $(\mathrm{m} / \mathrm{z}) 869.4445(\mathrm{M}+\mathrm{H})^{+}, 871.4424(\mathrm{M}+\mathrm{H})^{+}, 891.4274(\mathrm{M}+\mathrm{Na})^{+}$,
$893.4265(\mathrm{M}+\mathrm{Na})^{+}$(Bruker Daltonics GmbH, Bremen, Germany). UV-spectrum $\left(\lambda_{\max } \mathrm{nm}, \mathrm{MeOH}\right),(\varepsilon): 209$ (14000) (UV/VIS double beam spectrometer, UNICO, Dayton, NJ, USA); IR $\mathrm{V}_{\max }, \mathrm{cm}^{-1}$ (film) 3417, 2967, 2934, 2877, 1698, 1644, 1456, 1365, 1277, 1224, 1172, 1092, 1046, 982, 881 and 763 (Nicolet_iS10 Fourier transform IR spectrometer, Nicolet, Madison, WI, USA); $[\alpha]_{\mathrm{D}}{ }^{20}-83.3$ (c $\left.0.23, \mathrm{MeOH}\right)$ (AA55 Polarimeter, Optical Activity Ltd (Cambridge, UK)); $\mathrm{R}_{\mathrm{t}} 14.01$ (Shimadzu LC10 vp instrument, Kyoto, Japan, MeCN-0.01 $\mathrm{M} \mathrm{H}_{3} \mathrm{PO}_{4}$ mixture, $\mathrm{pH}$ 2.6. The percentage of MeCN increased from 20 to $22 \%$ within $15 \mathrm{~min}$, then to $90 \%$ within $15 \mathrm{~min}$ at a flow rate of $\left.1 \mathrm{ml} \mathrm{min}{ }^{-1}\right)$.

\section{ACKNOWLEDGEMENTS}

This study was supported by the grants of President of Russian Federation 'The Scientific School' (290.2010.4), Russian Foundation for Basic Research (10-0300210-a), and Ministry of Industry and Trade of Russian Federation (Contract no. 11411.1008700.13.078 at September 13, 2011).

1 Salomon, A. R., Voehringer, D. W., Herzenberg, L. A. \& Khosla, C Understanding and exploiting the mechanistic basis for selectivity of polyketide inhibitors of $F(0) F(1)$ ATPase. Proc. Natl Acad. Sci. USA 97, 14766-14771 (2000).

2 Lysenkova, L. N., Turchin, K. F., Danilenko, V. N., Korolev, A. M. \& Preobrazhenskaya, M. N. The first examples of chemical modification of oligomycin A. J. Antibiot. 63, 17-22 (2010).

3 Panek, J. S. \& Jain, N. F. J. Org. Chem 63, 4572-4573 (1998).

4 Bryskier, A. \& Veyssier, P. Ketolides In: Antibacterial and antifungals Ed. A. Bryskier, (ASM press: Washington DC, 2005) pp 527-569.

5 Shchekotikhin, A. E. et al. Synthesis and structure-activity relationship studies of 4,11diaminonaphtho[2,3-f]indole-5,10-diones. J. Bioorg. Med. Chem. 14, 5241-5251 (2006).

6 Reference Method for Broth Dilution Antifungal Susceptibility Testing of Yeasts; Approved Standard (NCCLS Document M27-A; NCCLS: Wayne, PA, 1997ISBN 1-56238-328-0).

7 Reference Method for Broth Dilution Antifungal Susceptibility Testing of Filamentous Fungi; Approved Standard (NCCLS Document M38-A; NCCLS: Wayne, PA, 2002ISBN 156238-470-8).

8 Ramirez, F., Marecek, J. F., Tu, S., Kantor, N. V. \& Okazaki, H. Effects of borohydridetreated oligomycins on processes of energy transduction in mitochondria. Eur. J. Biochem. 121, 275-279 (1982). 